\title{
MONITORING ENVIRONMENT WITH GIS FOR PART OF THIRUVALLUR TOWN USING CARTOSAT 1 STEREO, PAN \& RESOURCESAT LISS 4 MSS MERGED DATA.
}

\author{
Ghouse Shaik Mohamed $^{1 *}$ Ramakrishnan VenugopalVenkatchalam#, Mahendran.Ramamurthhy ${ }^{3 \#,}$ \\ Radhika Janakiraman Gummidipoondi ${ }^{4 \#}$, Murthy Ramillah ${ }^{5}$
}

\begin{abstract}
${ }^{1}$ Director Research,ghouse967@hotmail.com,9444055967, \#Asst Proff ${ }^{2}$ vvramkee2k@yahoo.co.in, ${ }^{3}$ softmahe@yahoo.com, 4mradhi.80@gmail.com, Sri Venkateswara college of Engineering Technology, Thirupachur ,Thiruvallur, Anna University, Chennai, Deputy Director ${ }_{2}^{5}$ murtyramillah@yahoo.com ,National Remote sensing Centre, Department of Space,Hyderabad, India,
\end{abstract}

\section{VIII/2: Health}

KEY WORDS: Environment, Thiruvallur, Population, Health GIS, Cartosat1 ,Resourcesat1LISS4

\begin{abstract}
:
Thiruvallur town is about $44 \mathrm{~km}$ from Chennai in Tamil nadu state of India with a population of 130000 , covering $10.75 \mathrm{sq} \mathrm{km}$ area. It is about $2 \mathrm{~km}$ from Sri Venkateswara College of Engineering and Technology. It was Taluk (Sub Division'.s) head quarters and from 1991 it was upgraded as District head quarters after the formation of Thiruvallur District. With rapid growth of town the Population density of Thiruvallur has increased in the past three decades from 300 persons/sq.km in 1951, to 6000 persons/sq.km in 1981 and now it is 12925 persons/sq.km in 2011. The creation of District administrative collector office, headquarters offices for police, judicial courts and Tamil Nadu and Federal Government development department's offices, establishment of multinationals major industries like Caterpillar, Kingfishers,Hindustan Motors, Mahendra Automobiles, Coco cola, Japanese Glass industry, Korean LOTO etc apart from mushrooming growth of about 41 Engineering, Nursing, Education, Medical, Naval, Arts and Science colleges, International Public schools,Governmentt, Private schools and Polytechnics added to the population of this Town. It is well connected by National Highways and Railways and upgraded as District Municipality. This resulted in urban drainage problem and conversion of Agriculture land and lakes for housing, establishment of major Govt and Private Hospitals including special units for Eye care, Cardiology, and Health Clinics, pharmacies etc. The effect of urbanization on environment of this once silent rural temple town which was supporting intensive agriculture activities, green with paddy fields is studied with high resolution satellite data is know the impact on health and environment changes from 2008 to 2011, using 2.5m resolution PAN stereo data of Cartosat 1 merged with 5.8 m resolution Multi Spectral data of LISS 4 of Resourcesat 1 of Indian Remote sensing satellites and Geo Eye satellite image of 2011 from Google Earth web site for the western part of Thiruvallur Municipality Area between North Western Thiruvallur town from the Temple Tank of Sri Veeraragavasamy temple to junction of National Highways connecting Thiruvallur to Tirupathi and Thiruvallur- Poondi- Uthukottai at the West. These data are used to create environment monitoring GIS to understand the use of High resolution Indian satellite data for local urban environmental planning to manage the health and environmental issues. ARC GIS 10 and Lieca photogrammetry software are used with satellite data to create different layer for creating GIS on urban infrastructure like houses, public buildings, roads, municipal surface drainage net work, underground sewerage drainage net work, drinking water pipe lines net work, landfills, solid waste disposal yards, pumping stations, degraded areas, heath services infrastructure, wet lands, low lying areas with bushes, abandoned lakes which are the breeding grounds for mosquito's in rainy season, etc These layers are correlated with the municipal ward map of this segment of the town. The stereo data of Cartosat 1 is useful for mapping the households, roads, agricultural fields, bushy areas, slopes to map the natural drainage of the area and for delineation of micro watersheds. When the layer of municipal ward maps are integrated with the GIS the drainage, drinking water lines, street names and house numbers etc can be added to the attribute data to make this as a complete Environment management GIS. The use of PAN merged data of Cartosat 1 with LISS 4, MSS Resourcesat 1 in natural colour and it's cost effectiveness is studied to explain the usefulness of creation of Environment Health GIS. The non stereo Geo Eye latest data from Google Earth web site or Cartosat 2 can be used for upgrading the land use changes and identify current environmental as on 2011. The study will provide GIS to monitor environmental issues with multi date large scale data for Thiruvallur Town.
\end{abstract}

\section{POPULATION DENSITY}

\subsection{Introduction}

According to the 2011 census Thiruvallur district has a population of 3,725,697 comparing the population of 2,754,756 in 2001 census. It is equal to the nation of Liberia or the US state of Oklahoma. It is given $70^{\text {th }}$ rank out of 640 Districts in India. The district has a population density of 1,049 inhabitants per square kilometre $(2,720 / \mathrm{sq} \mathrm{mi})$. Its population growth rate over the decade 2001-2011 was $35.25 \%$.Thiruvallur has a sex ratio of 983 females for every 1000 males, and a literacy rate of 83.82 $\%$.It occupies an area of $3424 \mathrm{~km}^{2}$. . It is $54.45 \%$ urbanized. 
The district has a literacy of $76.90 \%$, higher than the state average.

\subsection{Thiruvallur Town}

Thiruvallur is about $44 \mathrm{~km}$ from Chennai in Tamil nadu with a population of 1300000 , covering $10 \mathrm{sq} \mathrm{km}$ area, near our college and which was once a Sub Division, i.e. Taluk head quarters in Thiruvallur District till 1991. Population density of Thiruvallur has more than doubled in the past three decades. The town a population density of 300 persons/sq.km in 1951, population density rose to 6000 persons/sq.km in 1981 and 8600 persons/sq.km in 1991 and it has crossed 13000 per sq km in 2011

\subsection{Enviroinmental issues}

Due to creation of District administrative, police and judicial head quarters of Government Departments, major industries like Caterpillar, Kingfishers. Hindustan Motors etc and up gradation of it as District Municipality resulted in addition of urban infrastructure, drainage, conversion of Agriculture land and lakes as housing colonies etc The sewage also some times drains in tanks in rainy season. The lands near water spread are developed as housing plots disturbing the natural drainage system. The new housing colonies are flooded even for small intensity of rain fall. The urbanization of the town and villages which had narrow lanes developed for bullock carts movement are used by motor vehicles and two wheelers. Under ground drainage schemes are now under implentation in Tiruvallur. Till then the town has to depend on disposal of Night Soil is normally by way of individual facilities and liquid waste (Sullage and Kitchen Waste) is through the open drains. The main mode of individual disposal in the town is through 4613 septic tanks, low cost sanitation units and through public conveniences. There are 11 Private hospitals with 6 to 11 wards apart from Govt District hospital, 8 Medical Labs, 20 Pharmacy, Blood banks, Eye banks, Ambulance in Govt and Three private hospitals.

\section{RESEARCH}

Waste water disposal, drainage problems in the event of rains, encroachment of tanks, stagnant water bodies which are the breeding ground for mosquitoes and insects, interference to ancient planning of this religious historical towns and villages by haphazard modern housing urban development are studied and highlighted in this paper to demonstrate the use of high resolution data for creation of environment management GIS.The study has been taken up to understand the environmental issues to protect these areas. This research has been taken up using Cartosat 1 LISS 4 MSS data of Resourcesat 1, Google earth Geo eye data.The high resolution Indian satellite data are used for urban planning and creation of GIS for health, environment, town planning, and drainage system

\subsection{Cartosat and Liss IV Resourcesat data}

An attempt has been made to demonstrate the use Indian satellites data merged Cartosat 1, PAN $2.5 \mathrm{~m}$ resolution stereo data dated $27^{\text {th }}$ March 2007 with Resourcesat, Liss 4, $5.8 \mathrm{~m}$, Resolution multi spectral data dated 11 Jan 2005 to create high resolution imagery of part of Thiruvallur town and it"s neighborhood. The Google earth Geo eye data is used to update the latest land use as on 2011.The segment covering the part of Thiruvallur town in Tamil
Nadu from the Temple Tank of Sri Veeraragavasamy temple to West of National Highways from Thiruvallur to Tirupathi is selected for the study (Fig 1) to create Health GIS to demonstrate the use of high resolution Indian data for local urban planning to understand the Health and environmental problem areas to take remedial action by concerned.

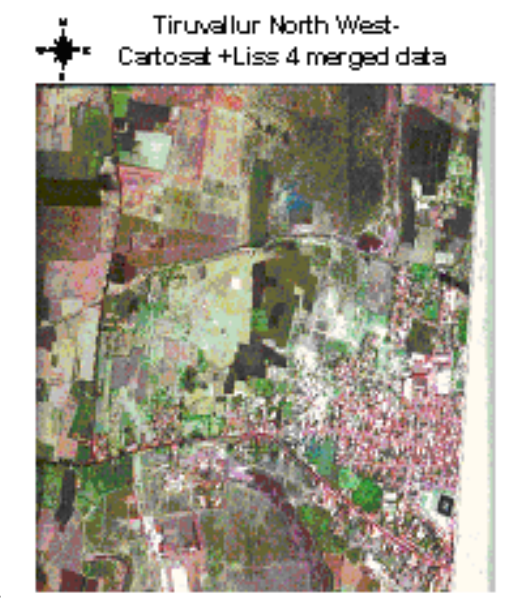

Figure.1.Segment of the PAN \&LISS 4 merged image of study area

While Arc GIs 10 software is used to create different themes and Lieca photogrammetry GIS software is used to create the contours to add topographical features of the study area from the Cartosat 1 streo data. Resourcesat data of Liss 4 was useful in mapping with ease the agriculture lands and other natural resources like gardens, water bodies ,urban areas, roads ,paths etc as the data is in colour. In fact the merged data in true colour is very much useful in digitizing various layers to create the Environment and Health GIS.

\subsection{Agriculture lands \& Gardens}

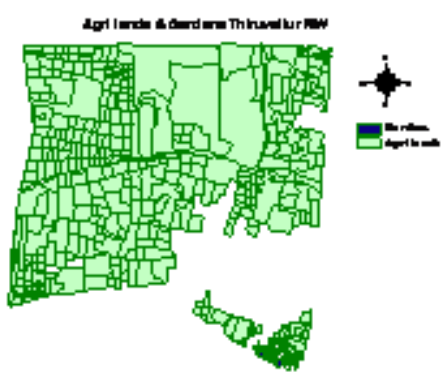

Figure.2.Agriculture and Garden Lands

The study area has irrigated farm lands of paddy, mango groves and tree plantations areas apart from dense populated urban area.These two layers are given in fig 2 . The irrigated agriculture lands and grooves have stagnant water in rainy season and irrigated paddy season. These areas are breeding grounds of insects and mosquitoes etc and creates problems like fever and cold. The irrigated agricultural lands also have reptiles like snakes which causes hazards like snake and insects bites. The undulating terrain condition adds to the surface drainage problems and 
stagnation of water etc These layers are correlated with the municipal ward map of this segment of the town.

\section{URBANAISATION}

The Town is growing in western and southern direction after the location of the district collectorate. Hence urbanization is the major issue to be considered while creating the health GIS. The fig 3 details shows Thirutani - Thiruvallur national highway and Uttukkottai Thiruvallur state highway.

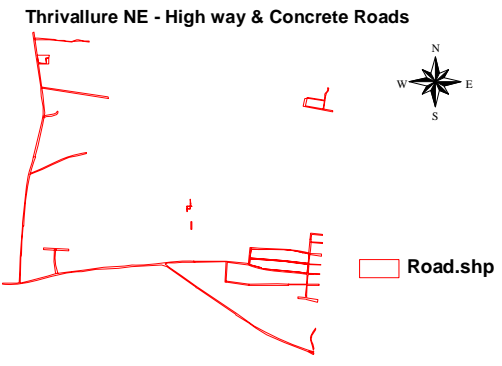

\subsection{Built up area}

Figure.3.Highways in Study Area

The old street houses, some of them are with remodeled houses without proper ventilation and drainage and built closely in narrow streets which were once used by bullock carts. These houses adds to the problem of environment and drainage. The layers of houses and vacant housing plots area are added to the road layer. The three layers are given in fig 4. These new housing plots are created by conversion of agriculture lands. This data is given in as a separate layer. The new house plots are in low lying areas. They have mud roads, drainage problem and have stagnation of water in rainy season and creates health problems. The local municipality is taking action to improve the roads and sewage drainage by laying under ground drainage to solve the health hazards because of open drainage channels in the streets.

\subsection{Marriage halls, Public gathering places}

The study area has more than 14 marriage function halls, 6 hotels and 4 mosques, 6 schools , four churches , two police station and part of Thiruvallur market. Apart from these The Veeraragavasmy temple and seven small temples are this area visited by Devotees going to Sri Vekateswara Thirumala Thirupathi Temple for various functions. The area needs care of environmental and health hazards issues to protect public gathering

The GIS of town will assist the concerned to manage the environmental and health hazards issues. It will also assist maintenance of the town by furnishing the data to get rid of open drainage channels, maintaining public gathering in several places for festivals and functions with proper planning for urbanization etc. The Figure 5 indiacte the low lying areas, the old town and the housing plots area. The paddy fields with crop and without crops and gardens can also be seen.

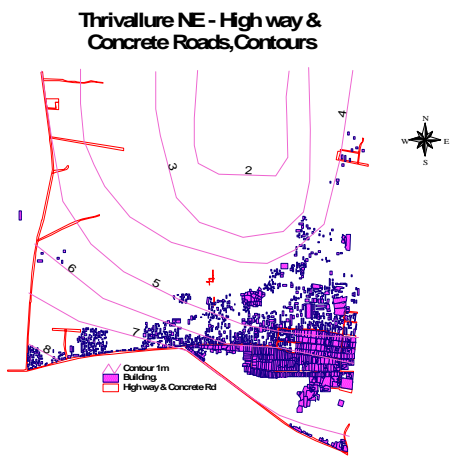

Figure.4. The Slope of study Area - Contour interval 1m

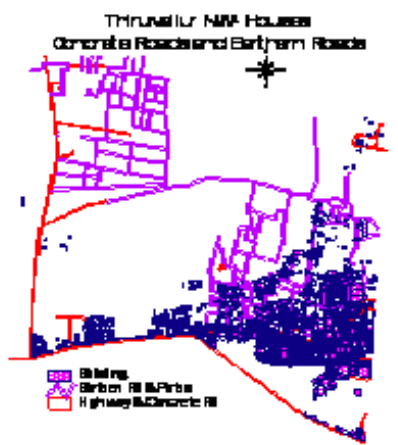

Figure.5.. Urban lands with buildings,roads,kutcha roads, tank and water bodies in the study area.

\section{THE SATELLITE DATA WITH ALL GIS LAYERS}

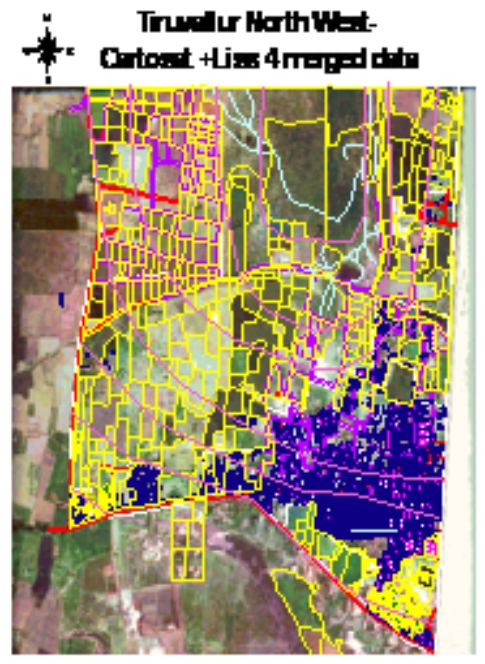

Figure.6. All GIS layers with satellite data

\subsection{Zonation to solve health issues}

Based on this study the pilot area is delineated in to zones as detailed in Figure 7 to monitor and manage the health and environmental issues. The zones are agriculture lands, Villages, old town, housing plots, layouts, new housing colonies etc. This grouping will make help the implementing agencies to draw a plan to solve the environment and health issues. 


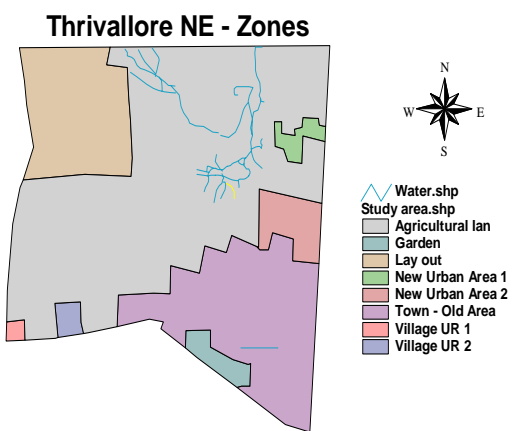

Figure.7. Study Area Health Zones

\subsection{Thiruvallur Temple tank}

As urbanisataion started from 1940 to 1970 the tank is not getting water from near by water sources. The feeder channels were closed due to construction of houses near the temples. The outer tank (Figure 8) area has been polluted and used as solid waste dumping yard. The baby tank in the

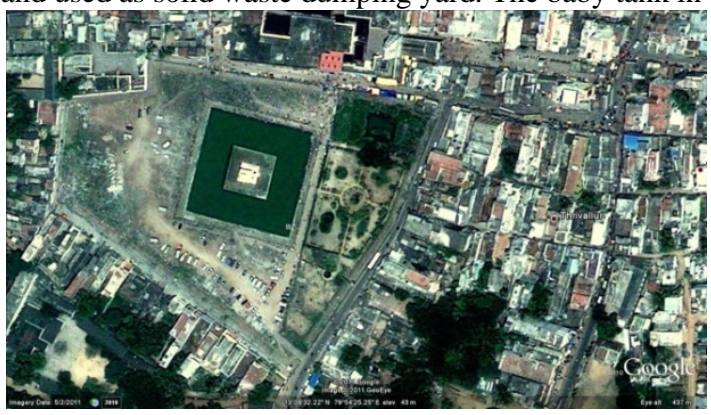

Figure .8. Temple Tank Thiruvallur

Temple tank is now filled with water. The outer tank area is developed now as a park with roads and Car and Vehicle Park area.(Figure 9). The reduction of storage in tanks has lead to depletion of good quality ground water. The houses near by depends on 70to 100 feet bore wells to tap water from the unconfined aquifer.

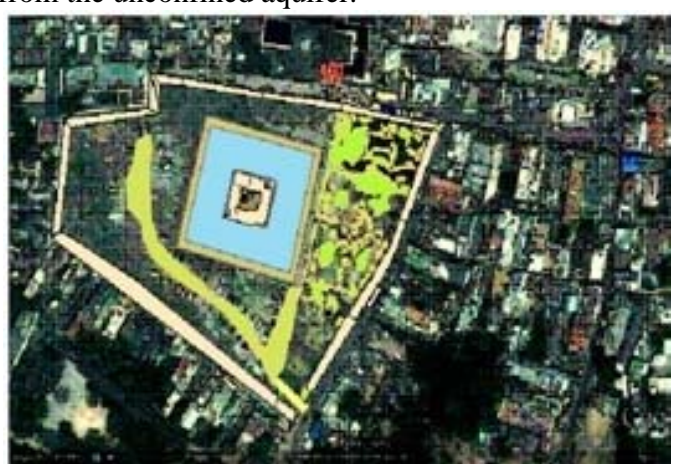

Figure .9.Temple Thiruvallur with Tank Park \& Roads Using shallow open wells which were recharged from the water stored in the outer tank is a thing of past. This town now depends on Poondi reservoir for drinking water by Public Water Distribution system.

4.3.High resolution data to study Urbanisation impacts Urbanization, industrialization, increase in no of engineering colleges and Higher education institutes, has transformed this rural area as a nodal centre for Industry, education and other services.

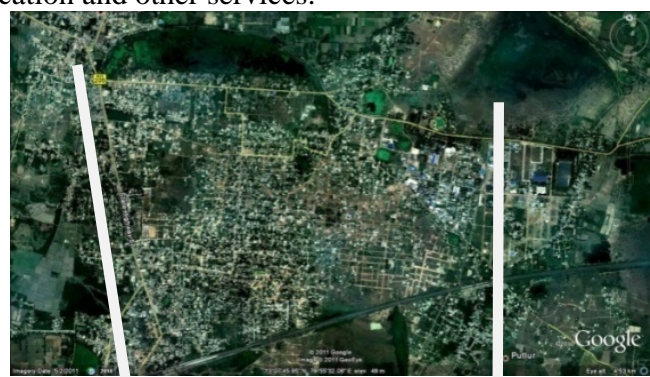

Figure 10. Part of Thiruvallur Town 'Central )

This area shown above is near the Cer ral Bus station between the I'wo Major tanks in the North and Cooum river near Thi uvallur - Chennai Railway line. This area was once was I nder intensive agriculture. The tanks in the above and. are i ıdicated with blue colour ir Fig. below.

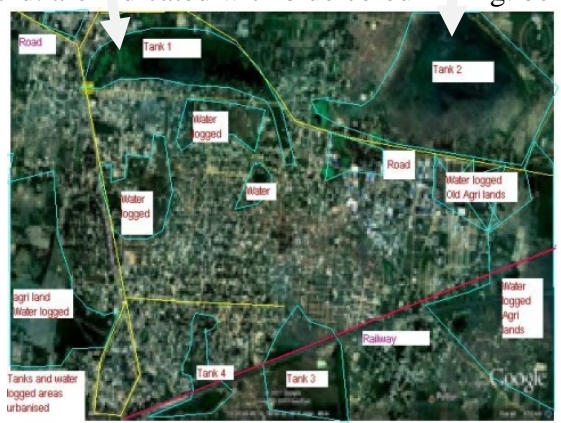

Figure 11. Thiruvallur Town Part ( Central )with details of water bodies

\section{IMPACT OF INCREASE IN POPULATION DENSITY}

The population density has increased by 26 times from 500 per sq $\mathrm{km}$ in 1951 to 13000 per sq $\mathrm{km}$ in 2011. The image below shows the houses and housing plots near between railway station and bus stand.(Fig.15) The cluster houses

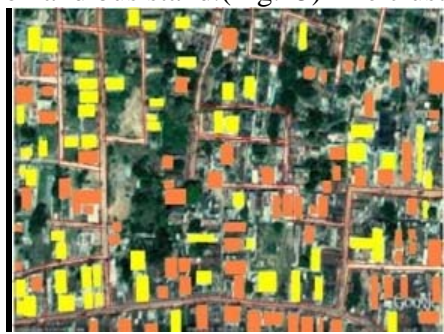

Figure 12.Houses and Plots near Thiruvallur Station Individual Houses plotted from High Resolution data.

shown above need surface water and under ground sewage system .The water resources like tanks are degraded and some are used for dumping yard for waste. The sewage also some times drains in rainy season. The lands near water spread are developed as housing plots disturbing the natural drainage system. These new housing colonies are flooded even for small intensity of rain fall.

5.1.Ecologic and Environment impact on urban structures.

Solid waste management and Waste water disposal are observed as main drainage problems in the event of rains. 


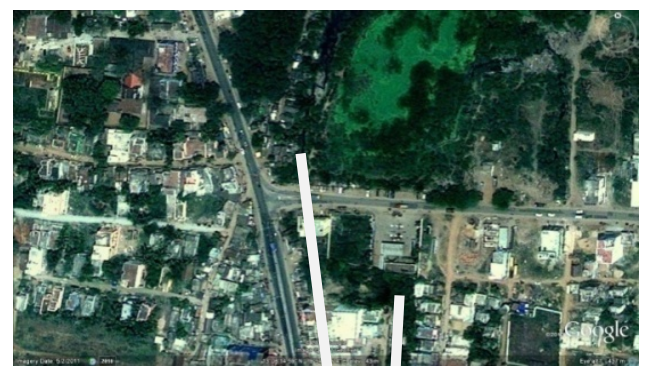

Figure.13.Part of the Tank nec : Bus stand polluted

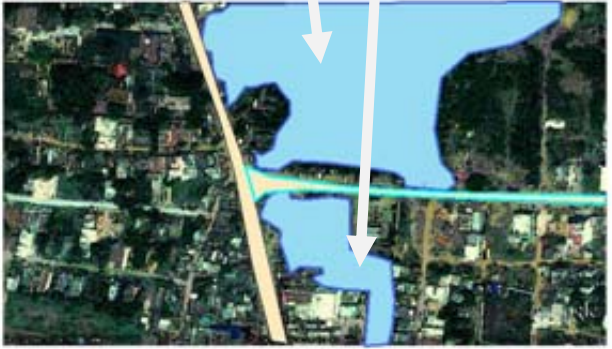

Figure.14.The water stagnant areas of above tank.

The images details the water logging area near Thiruvallur Railway station and at Cooum river stagnant water bodies. These may the breeding ground for mosquitoes and insects if care is not taken. Interference of ancient planning of this religious historical towns and villages by haphazard modern housing urban development are other major issues noticed in this study and are highlighted in this paper to demonstrate the use of high resolution data for creation of environment management GIS.

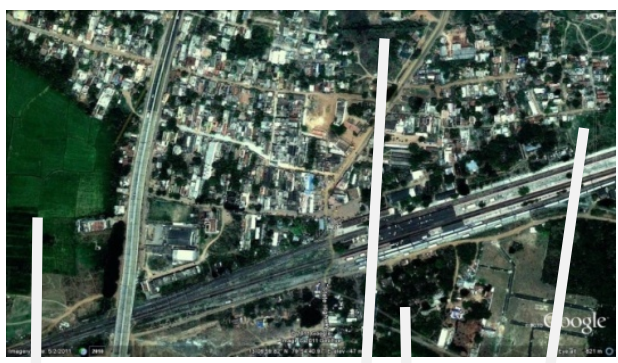

Fig.16.Area nı ar ailway stat on.

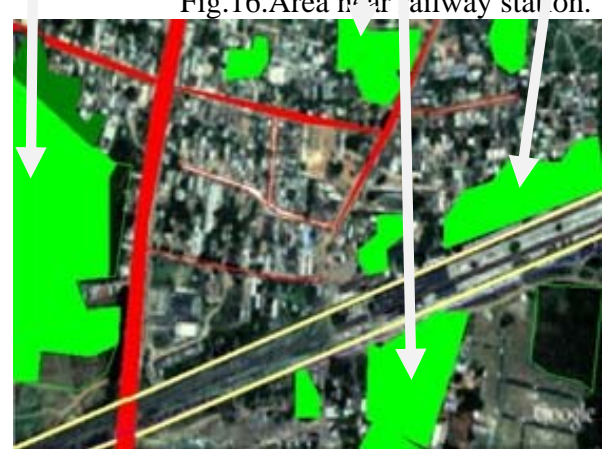

Figure.16.The low lying area near railway station from High Resolution data, encroachment of water bodies 7.Conclusions

The study details the fact that the high resolution data available in google map - Geo Eye data and Indian satellites like Cartosat 1 data and Liss 4 Resourcesat merged data and Cartosat 2 Data can make the work of environmental and ecological managers easy as the eco degradation problems can be studied with maped and analysis can be done adding non spatial data to the attribute table of GIS.

The places like Thiruvallur which have high density of population and town ship created by converting wet lands in river basin should be mapped with 1:1000 scale GIS to improve ecology and environment. The GIS of the town can be studied by delineating in to Environment and Health Zones as detailed above.It is observed that LISS, 4, $5.8 \mathrm{~m}$ Resolution data is useful is creating Gis for Health to understand problems from water bodies and abandoned lakes and cultivated lands for this town which was a wet land surrounded by cultivated paddy fields.

The Cartosat 1 stereo data is useful for mapping the households, roads, agricultural fields, bushy areas and to understand the natural drainage and topography of the area. When the municipal ward maps are integrated with the GIS the drainage, drinking water lines, street names and house nos etc can be added to the attribute data.

If Cartosat $21 \mathrm{~m}$ data is used the individual house hold can be clearly mapped. It is observed that the PAN merged data of Cartosat 1 and LISS 4 still meets the need of Health Gis as almost all information can be given. It is cost effective and most suitable to under stand the terrain due to the Stereo Capability of Cartosat 1.

Liss III 22.8 m Resourcesat Indian data was useful to study the Cooum basin and degradation by conversion of wet lands in to housing plots. The programmes can be taken up to reclaim the areas by reducing pollution and ecological problems by the concerned implementing agency to have a safe environmental living.

The Geo Eye data from Google earth of 2011 is useful include latest data for understanding health and environmental problems to update Environment and health GIS

Ref

Mohamed Ghouse Shaik, Ramakrishnan VV, Radika GJ 2012 Management of environmental issues of Cooum basin at Thiruvallur in Tamil nadu using High resolution Indian Satellite data and GIS..69 Geospatial World forum, Amsterdam The Netherlands

Dr S.Mohamed Ghouse, V.Ramakrishnan, J.Radhika, V.Balamurugan , 2009, Heath GIS for part of Thiruvallur town using Cartosat1 \& Liss 4 Pan merged data,AIT Bangkok, GTDM 4 Health GIS international conference, Hyderabad

Mohamed Ghouse shaik, Senthil Kumar, Sabapatrhy Rethina and RLN Murthy, 2008, Evaluation of Perth city data of Indian Remote sensing Satellites to built Green Australia to meet the environmental and ecological challenges of $21^{\text {st }}$ Century Australian 14th Remote sensing photogrammerty conference, Darwin, Australia. 
International Archives of the Photogrammetry, Remote Sensing and Spatial Information Sciences, Volume XXXIX-B8, 2012 XXII ISPRS Congress, 25 August - 01 September 2012, Melbourne, Australia 